\title{
Nocardioides hungaricus sp. nov., isolated from a drinking water supply system
}

\author{
Erika M. Tóth, ${ }^{1}$ Zsuzsa Kéki, ${ }^{1}$ Judit Makk, ${ }^{1}$ Zalán G. Homonnay, ${ }^{1}$ \\ Károly Márialigeti ${ }^{1}$ and Peter Schumann ${ }^{2}$ \\ ${ }^{1}$ Eötvös Loránd University, Faculty of Science, Department of Microbiology, Pázmány Péter sétány \\ 1/c, $\mathrm{H}-1117$ Budapest, Hungary \\ ${ }^{2}$ DSMZ-German Collection of Microorganisms and Cell Cultures, Inhoffenstrasse 7B, D-38124 \\ Braunschweig, Germany
}

Correspondence

Erika M. Tóth

totherika@ludens.elte.hu

\begin{abstract}
Three Gram-positive, rod-shaped bacterial strains were isolated from the drinking water supply system of the Hungarian capital, Budapest. Phylogenetic analysis on the basis of 16S rRNA gene sequence comparison revealed that the isolates represented a distinct cluster within the clade of the genus Nocardioides and were most closely related to Nocardioides pyridinolyticus $\mathrm{OS} 4^{\top}$, Nocardioides aquiterrae GW-9 ${ }^{\top}$, Nocardioides sediminis $\mathrm{MSL}-01^{\top}$ and $N$. hankookensis DS-30' ${ }^{\top}$. The peptidoglycan based on LL-2,6-diaminopimelic acid, the major menaquinone MK$8\left(\mathrm{H}_{4}\right)$, the cellular fatty acid profile with iso- $\mathrm{C}_{16: 0}$ and anteiso- $\mathrm{C}_{17: 0}$ as predominating components and the DNA G $+C$ content of 71.4 mol\% (strain 1 RaM5-12 ${ }^{T}$ ) were consistent with the affiliation of the isolates to the genus Nocardioides. Because of differences in physiological characteristics, matrix-assisted laser-desorption/ionization time-of-flight mass spectra of protein extracts, Pvull RiboPrinter patterns and 96.1\% 16S rRNA gene sequence similarity between strain 1 RaM5 $-12^{\top}$ and its closest phylogenetic neighbour, N. pyridinolyticus $\mathrm{OS}^{\top}$, a novel species, Nocardioides hungaricus sp. nov., is proposed. The type strain is 1 RaM5-12 $2^{\top}$ (=DSM $21673^{\top}=$ NCAIM $02330^{\top}$ ).
\end{abstract}

Drinking water systems represent distinct oligotrophic microbiological habitats, where the supplied water and different sites of the pipelines can be colonized by microbes, including bacteria. In these aquatic ecosystems, bacteria adapt to the extreme environment and are able to grow, often forming well-developed biofilms on the internal surfaces of pipelines (Garrett et al., 2008). The drinking water of the Hungarian capital, Budapest, originates from riverbank filtration wells located on the River Danube. It is treated only by chlorination before its supply to users (Homonnay et al., 2008).

The genus Nocardioides comprises 47 species at the time of writing, the type strains of which have been isolated from various sources, e.g. aquatic habitats [Nocardioides aquiterrae (Yoon et al., 2004), Nocardioides aquaticus (Lawson et al., 2000) and Nocardioides marinus (Choi et al., 2007)], meadow [Nocardioides plantarum (Collins et al., 1994)] and polluted environments [Nocardioides oleivorans (Schippers

Abbreviation: MALDI-TOF, matrix-assisted laser-desorption/ionization time-of-flight.

The GenBank/EMBL/DDBJ accession numbers for the 16S rRNA gene sequences of strains 1 RaM5-12 ${ }^{\top}, 1$ RaM5-3 and 1RaM5-15 are AM981198, AM981197 and AM981199, respectively.

A supplementary table and two supplementary figures are available with the online version of this paper. et al., 2005), Nocardioides nitrophenolicus (Yoon et al., 1999), Nocardioides pyridinolyticus (Yoon et al., 1997) and Nocardioides aromaticivorans (Kubota et al., 2005)]. The recently described species Nocardioides daphniae (Tóth et al., 2008b) was isolated from the crustacean Daphnia cucullata, Nocardioides hankookensis (Yoon et al., 2008), Nocardioides tritolerans (Dastager et al., 2008b) and Nocardioides islandensis (Dastager et al., 2008a) were isolated from soil and Nocardioides sediminis (Dastager et al., 2009) was isolated from sediment.

A water sample of Tahi, Hungary $\left(47^{\circ} 45^{\prime} \mathrm{N} 19^{\circ} 05^{\prime} \mathrm{E}\right)$, a collecting point of well water in the drinking water supply system of Budapest, was taken in 2007. Strains 1RaM5-12 ${ }^{\mathrm{T}}$, 1RaM5-3 and 1RaM5-15 were isolated on R2A agar (Reasoner \& Geldreich, 1985) after a standard spread-plate method and incubation at $28{ }^{\circ} \mathrm{C}$ for 1 week. The isolates were maintained on R2A agar. Colony morphology was studied on R2A agar by direct and stereomicroscopic observations of single colonies. Cell size, shape, arrangement and motility of the isolates were studied by native preparations and by Gram-staining according to Claus (1992). Endospore- and acid-fast-staining methods followed Murray et al. (1994).

Growth under anaerobic conditions was examined using R2A slant agar cultures incubated for 1 week in an 
anaerobic chamber (Forma Scientific) at $28{ }^{\circ} \mathrm{C}$. Oxidase activity was tested by the method of Tarrand \& Gröschel (1982). Catalase production and Voges-Proskauer reaction were demonstrated by the methods of Cowan \& Steel (1974). Acid production from glucose was studied by the OF test according to Hugh \& Leifson (1953). Growth at 4, 20, 28, 37 and $45{ }^{\circ} \mathrm{C}$ was determined on R2A agar and growth with $0,2.5,5$ and $10 \%(\mathrm{w} / \mathrm{v}) \mathrm{NaCl}$ and at $\mathrm{pH} 4-12$ (at intervals of one $\mathrm{pH}$ unit) was determined in R2A broth. Urease activity, nitrate reduction, starch hydrolysis, indole production from tryptophan, caseinase, gelatinase and phosphatase activity, hydrolysis of Tween 80 and $\mathrm{H}_{2} \mathrm{~S}$ production from cysteine were studied according to Smibert \& Krieg (1994). Substrate utilization, other physiological properties and enzyme activities were tested using the API $20 \mathrm{NE}$, API $50 \mathrm{CH}$ and API ZYM systems (bioMérieux), according to manufacturer's instructions.

The cell-wall diamino acid of strain 1 RaM5 $-12^{\mathrm{T}}$ was determined from whole-cell hydrolysates as described by Hasegawa et al. (1983). Isoprenoid quinones were extracted from cells cultivated in liquid Rich medium (Yamada \& Komagata, 1972) according to the method of Collins et al. (1977) and the profile was analysed by HPLC (HP 9001; Hewlett Packard) (Groth et al., 1997). Cellular fatty acids were extracted from cells cultivated on trypticase soy agar (Difco) at $28{ }^{\circ} \mathrm{C}$ for $48 \mathrm{~h}$ according to Stead et al. (1992) and analysed by gas chromatography (Groth et al., 1996). Summed features were identified thereafter by GC/MS using a Singlequad 320 instrument (Varian). Polar lipids were determined according to the method described by Minnikin et al. (1979). Genomic DNA for analysis of the base composition was isolated after disruption of bacterial cells using a French pressure cell (Thermo Spectronic). After purification on hydroxyapatite according to the procedure of Cashion et al. (1977), the DNA was degraded to nucleosides using P1 nuclease and bovine intestinal mucosa alkaline phosphatase as described by Mesbah et al. (1989). The nucleosides were separated by reversed-phase HPLC (Shimadzu LC 20A) according to the method described by Tamaoka \& Komagata (1984). The G+C content of the DNA was calculated from the ratio of deoxyguanosine to thymidine.

Extraction of DNA from strains 1 RaM5-12 ${ }^{\mathrm{T}}, 1 \mathrm{RaM} 5-3$ and 1RaM5-15 and PCR-mediated amplification of the 16S rRNA gene were carried out by the method of Rainey et al. (1996). The PCR products were purified with a Prep-AGene kit (Bio-Rad). Cycle sequencing was performed with a Big Dye terminator cycle sequencing kit, according to the manufacturer's protocol, and sequence analysis was performed using a model 310 Genetic Analyzer (Applied Biosystems). The search for phylogenetic neighbours was initially carried out using BLAST (Altschul et al., 1997) and FASTA (Pearson \& Lipman, 1988) and a database of sequences of type strains with validly published prokaryotic names (Chun et al., 2007). Pairwise 16S rRNA gene sequence similarities were calculated using the SimTable analysis of the EzTaxon server (http://www.eztaxon.org).
The 16S rRNA gene sequences of strains 1 RaM $5-12^{\mathrm{T}}$, 1RaM5-3 and 1RaM5-15 were aligned against sequences available from the GenBank database (http://www.ncbi. nlm.nih.gov/) and phylogenetic and molecular evolutionary analyses were conducted using MEGA version 4 (Tamura et al., 2007). Evolutionary distances were calculated using Kimura's two-parameter model (Kimura, 1980) and phylogenetic dendrograms were reconstructed using the neighbour-joining (Saitou \& Nei, 1987), minimum-evolution (Rzhetsky \& Nei, 1992) and maximum-parsimony (Fitch, 1971) methods. Bootstrap analysis was based on 1000 resamplings (Felsenstein, 1985).

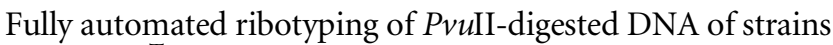
1RaM5-12 ${ }^{\mathrm{T}}, 1 \mathrm{RaM} 5-3$ and 1 RaM5-15 was performed with the RiboPrinter system (DuPont Qualicon) as described by Bruce (1996). Matrix-assisted laser-desorption/ionization time-of-flight (MALDI-TOF) mass spectrometry was carried out as described previously (Tóth et al., 2008a).

The detailed morphological, cultural and physiological characteristics of strains 1RaM5-12 2 , 1RaM5-3 and 1RaM5-15 are given in the species description and in Table 1. The chemotaxonomic analyses confirmed that the isolates belonged to the genus Nocardioides in that they had LL-2,6-diaminopimelic acid in their cell walls, the major isoprenoid quinone was $\mathrm{MK} 8\left(\mathrm{H}_{4}\right)$ and the only polar lipid was diphosphatidylglycerol. The fatty acid profiles of strains 1RaM5-12 ${ }^{\mathrm{T}}, 1 \mathrm{RaM} 5-3$ and $1 \mathrm{RaM} 5-15$ are given in Supplementary Table S1 (available in IJSEM Online). The fatty acid profiles of the three isolates were similar qualitatively in the major components and were in this respect similar to those reported for $N$. pyridinolyticus and N. aquiterrae (Yoon et al., 2004). However, the fatty acid profiles were different from those reported for N. sediminis and N. hankookensis (Dastager et al., 2009; Yoon et al., 2008 ) by having remarkably lower amounts of $\mathrm{C}_{17: 1} \omega 8 c$, which was most probably because of differences in cultivation and extraction conditions. Other phenotypic characters that differentiate our strains from their closest relatives are given in Table 1. The DNA G $+\mathrm{C}$ content of strain 1 RaM $5-12^{\mathrm{T}}$ was $71.4 \mathrm{~mol} \%$.

The neighbour-joining phylogenetic tree (Fig. 1) based on nearly complete (1462 bp) 16S rRNA gene sequences showed that strains 1 RaM5-12 ${ }^{\mathrm{T}}, 1 \mathrm{RaM} 5-3$ and 1 RaM5-15 formed a distinct group within the genus Nocardioides. The phylogenetic trees recreated using the minimum-evolution and maximum-parsimony algorithms resulted in similar tree topologies (Fig. 1). The closest relatives of the isolates were $N$. pyridinolyticus $\mathrm{OS} 4^{\mathrm{T}}, N$. aquiterrae $\mathrm{GW}-9^{\mathrm{T}}, N$. sediminis MSL- $01^{\mathrm{T}}$ and $N$. hankookensis DS- $30^{\mathrm{T}}$ : $16 \mathrm{~S}$ rRNA gene sequence similarities between strain $1 \mathrm{RaM} 5-12^{\mathrm{T}}$ and these type strains were 96.1, 95.7, 95.4 and 95.4\%, respectively. $16 \mathrm{~S}$ rRNA gene sequence similarities between the isolates and all other members of the genus Nocardioides were lower than $95.2 \%$.

The three isolates were shown to be very closely related. $16 \mathrm{~S}$ rRNA gene sequence similarities with each other were: $99.2 \%$ 
Table 1. Differential phenotypic characteristics of strains $1 \mathrm{RaM5}-12^{\top}, 1 \mathrm{RaM} 5-3$ and $1 \mathrm{RaM} 5-15$ and their closest phylogenetic neighbours

Strains: 1, Nocardioides hungaricus sp. nov. 1RaM5-12 ; 2, N. hungaricus sp. nov. 1RaM5-3; 3, N. hungaricus sp. nov. 1RaM5-15; 4, N. pyridinolyticus $\mathrm{OS}^{\mathrm{T}}$; 5, N. aquiterrae GW-9 ${ }^{\mathrm{T}} ; 6$, N. hankookensis DS-301 ${ }^{\mathrm{T}}$. Data were taken from Yoon et al. (2008) and this study. C, Coccus; $\mathrm{R}$, rod; +, positive; $\mathrm{w}$, weakly positive; - , negative; ND, not determined.

\begin{tabular}{|c|c|c|c|c|c|c|}
\hline Characteristic & 1 & 2 & 3 & 4 & 5 & 6 \\
\hline Colony colour & White & White & White & Cream & Cream & White \\
\hline \multicolumn{7}{|l|}{ Cell characteristics } \\
\hline Width $(\mu \mathrm{m})$ & $0.4-0.6$ & $0.5-0.6$ & $0.5-0.6$ & $0.5-0.6$ & $0.8-1.0$ & $0.4-0.8$ \\
\hline Length $(\mu \mathrm{m})$ & $0.9-1.7$ & $0.9-1.6$ & $1.0-1.7$ & $1.2-1.6$ & $1.7-2.0$ & $1.5-10.0$ \\
\hline Rod-coccus cycle & - & - & - & + & + & - \\
\hline \multicolumn{7}{|l|}{ Optimal growth conditions } \\
\hline Temperature $\left({ }^{\circ} \mathrm{C}\right)$ & $20-28$ & $20-28$ & $20-28$ & 35 & 30 & 25 \\
\hline $\mathrm{pH}$ & $6-7$ & $6-7$ & $6-7$ & 8 & $6-7$ & $6-7$ \\
\hline $\mathrm{NaCl}(\%)$ & $0-2.5$ & $0-2.5$ & $0-2.5$ & $\mathrm{ND}$ & $\mathrm{ND}$ & $0-0.5$ \\
\hline Oxidase & - & - & - & - & + & + \\
\hline Nitrate reduction to nitrite & + & + & + & + & + & - \\
\hline Casein & - & - & - & ND & + & ND \\
\hline Gelatin & + & - & - & + & ND & ND \\
\hline Tween 80 & + & + & + & - & + & $\mathrm{w}$ \\
\hline Starch & - & - & - & + & - & + \\
\hline \multicolumn{7}{|l|}{ Enzyme activities } \\
\hline Alkaline phosphatase & + & + & + & + & - & + \\
\hline Esterase $(\mathrm{C} 4)$ & + & + & + & - & - & + \\
\hline Lipase (C14) & $\mathrm{w}$ & + & + & - & - & - \\
\hline$\beta$-Galactosidase & + & $\mathrm{w}$ & + & - & - & - \\
\hline Valine arylamidase & $\mathrm{w}$ & - & - & $\mathrm{w}$ & - & - \\
\hline Cystine arylamidase & - & - & - & + & + & - \\
\hline
\end{tabular}

between strains 1RaM5-12 ${ }^{\mathrm{T}}$ and 1RaM5-15; $99.6 \%$ between strains 1 RaM5-12 ${ }^{\mathrm{T}}$ and 1 RaM5-3; and $99.7 \%$ between strains 1RaM5-15 and 1RaM5-3. Their close relationship was also confirmed by the RiboPrinter results (Supplementary Fig. S1) and MALDI-TOF analysis (Supplementary Fig. S2) as well as many other phenotypic characteristics (Table 1).

Based on the distinctive genotypic, chemotaxonomic and phenotypic characteristics, strains 1 RaM5-12 ${ }^{\mathrm{T}}$, 1RaM5-3 and 1RaM5-15 are considered to represent a novel species within the genus Nocardioides, for which the name Nocardioides hungaricus sp. nov. is proposed.

\section{Description of Nocardioides hungaricus sp. nov.}

Nocardioides hungaricus (hun.ga'ri.cus. M.L. masc. adj. hungaricus Hungary, the name of the country where the species was first isolated).
Gram-positive (Gram-variable in old cultures), acid-fast, non-endospore-forming bacterium. Cells are non-motile and exhibit aerobic respiratory metabolism. Catalase-positive and oxidase-negative. Cells do not show a rod-coccus cycle from the early exponential phase to the stationary phase. Neither substrate nor primary mycelium is formed. Colonies on R2A agar are white, smooth, circular and convex after 7 days at $28{ }^{\circ} \mathrm{C}$. Cells are $0.4-0.6 \times 0.9-1.7 \mu \mathrm{m}$ after 1 day on R2A agar at $28{ }^{\circ} \mathrm{C}$. Growth occurs at $20-37{ }^{\circ} \mathrm{C}$ (optimum $20-28{ }^{\circ} \mathrm{C}$ ), at $\mathrm{pH} 5-9$ (optimum $\mathrm{pH} 6-7$ ) and with $0.0-2.5 \% \mathrm{NaCl}$. Glucose is not degraded under oxidative-fermentative conditions. Urease and phosphatase activity, VogesProskauer and methyl-red reactions, and indole and $\mathrm{H}_{2} \mathrm{~S}$ production are negative. Nitrate is reduced to nitrite. With API $50 \mathrm{CH}$, hydrolyses aesculin; all other test results are negative. Positive for alkaline phosphatase, esterase (C4), esterase lipase (C8), lipase (C14), leucine arylamidase, valine 


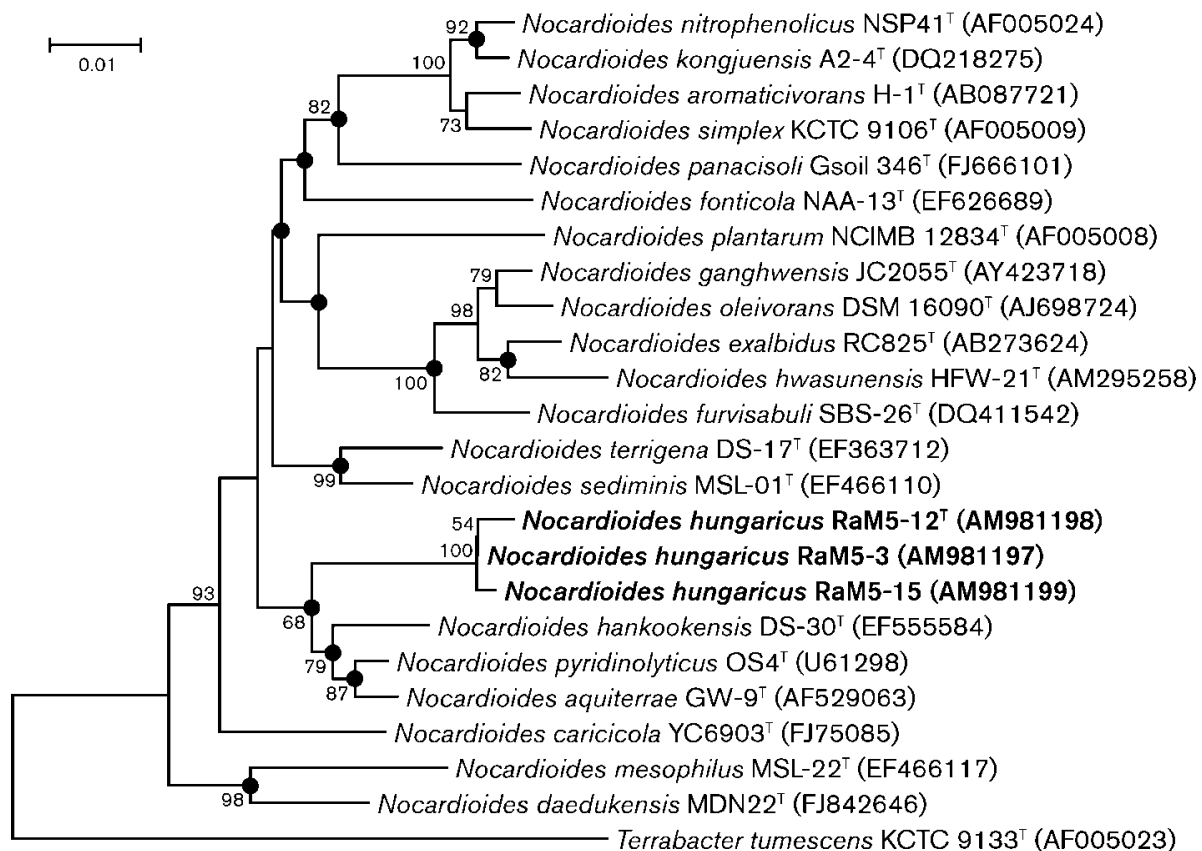

Fig. 1. 16S rRNA gene sequence neighbour-joining tree showing the phylogenetic positions of strains $1 \mathrm{RaM}^{\mathrm{R}}-12^{\top}, 1 \mathrm{RaM} 5-3$ and $1 \mathrm{RaM} 5-15$ among closely related members of the genus Nocardioides. Bootstrap values ( $>50 \%)$ based on 1000 resamplings (Felsenstein, 1985) are shown at branch nodes. Filled circles indicate that the corresponding nodes were recovered in the minimum-evolution and maximum-parsimony trees. Bar, 1 substitution per 100 nucleotide positions.

arylamidase, acid phosphatase, naphthol-AS-BI-phosphohydrolase, $\beta$-galactosidase, $\alpha$-glucosidase and $\beta$-glucosidase. The diagnostic diamino acid in the cell-wall peptidoglycan is LL-2,6-diaminopimelic acid. The predominant menaquinone is $\mathrm{MK}-8\left(\mathrm{H}_{4}\right)$. The major fatty acids $(>5 \%)$ are iso- $\mathrm{C}_{16: 0}$ and anteiso- $\mathrm{C}_{17: 0}$. The DNA G $+\mathrm{C}$ content of the type strain is $71.4 \mathrm{~mol} \%$.

The type strain is 1 RaM5- $12^{\mathrm{T}}\left(=\mathrm{DSM} 21673^{\mathrm{T}}=\right.$ NCAIM $02330^{\mathrm{T}}$ ), isolated from the drinking water network of Budapest, Hungary.

\section{References}

Altschul, S. F., Madden, T. L., Schäffer, A. A., Zhang, J., Zhang, Z., Miller, W. \& Lipman, D. J. (1997). Gapped BLAST and PSI-BLAST: a new generation of protein database search programs. Nucleic Acids Res 25, 3389-3402.

Bruce, J. (1996). Automated system rapidly identifies and characterizes microorganisms in food. Food Technol 50, 77-81.

Cashion, P., Holder-Franklin, M. A., McCully, J. \& Franklin, M. (1977). A rapid method for the base ratio determination of bacterial DNA. Anal Biochem 81, 461-466.

Choi, D. H., Kim, H. M., Noh, J.-H. \& Cho, B. C. (2007). Nocardioides marinus sp. nov. Int J Syst Evol Microbiol 57, 775-779.

Chun, J., Lee, J.-H., Jung, Y., Kim, M., Kim, S., Kim, B. K. \& Lim, Y.-W. (2007). EzTaxon: a web-based tool for the identification of prokaryotes based on $16 \mathrm{~S}$ ribosomal RNA gene sequences. Int J Syst Evol Microbiol 57, 2259-2261.

Claus, M. (1992). A standardized Gram staining procedure. World J Microbiol Biotechnol 8, 451-452.
Collins, M. D., Pirouz, T., Goodfellow, M. \& Minnikin, D. E. (1977). Distribution of menaquinones in actinomycetes and corynebacteria. J Gen Microbiol 100, 221-230.

Collins, M. D., Cockcroft, S. \& Wallbanks, S. (1994). Phylogenetic analysis of a new LL-diaminopimelic acid-containing coryneform bacterium from herbage, Nocardioides plantarum sp. nov. Int J Syst Bacteriol 44, 523-526.

Cowan, S. T. \& Steel, K. J. (1974). Cowan and Steel's Manual for the Identification of Medical Bacteria, 2nd edn. London: Cambridge University Press.

Dastager, S. G., Lee, J.-C., Ju, Y.-J., Park, D.-J. \& Kim, C.-J. (2008a). Nocardioides islandiensis sp. nov., isolated from soil in Bigeum Island Korea. Antonie van Leeuwenhoek 93, 401-406.

Dastager, S. G., Lee, J.-C., Ju, Y.-J., Park, D.-J. \& Kim, C.-J. (2008b). Nocardioides tritolerans sp. nov., isolated from soil in Bigeum Island, Korea. J Microbiol Biotechnol 18, 1203-1206.

Dastager, S. G., Lee, J.-C., Ju, Y.-J., Park, D.-J. \& Kim, C.-J. (2009). Nocardioides sediminis sp. nov., isolated from a sediment sample. Int J Syst Evol Microbiol 59, 280-284.

Felsenstein, J. (1985). Confidence limits on phylogenies: an approach using the bootstrap. Evolution 39, 783-789.

Fitch, W. M. (1971). Towards defining the course of evolution: minimum change for a specific tree topology. Syst Zool 20, 406-416.

Garrett, T. R., Bhakoo, M. \& Zhang, Z. (2008). Bacterial adhesion and biofilms on surfaces. Prog Nat Sci 18, 1049-1056.

Groth, I., Schumann, P., Weiss, N., Martin, K. \& Rainey, F. A. (1996). Agrococcus jenensis gen. nov., sp. nov., a new genus of actinomycetes with diaminobutyric acid in the cell wall. Int J Syst Bacteriol 46, 234-239.

Groth, I., Schumann, P., Rainey, F. A., Martin, K., Schuetze, B. \& Augsten, K. (1997). Demetria terragena gen. nov., sp. nov., a new 
genus of actinomycetes isolated from compost soil. Int J Syst Bacteriol 47, 1129-1133.

Hasegawa, T., Takizawa, M. \& Tanida, S. (1983). A rapid analysis for chemical grouping of aerobic actinomycetes. J Gen Appl Microbiol 29, 319-322.

Homonnay, Z. G., Makk, J., Brumbauer, A., Párkány-Simon, B., Márialigeti, K. M. \& Tóth, E. (2008). Investigations on the bacterial community of two characteristic sites of drinking water network of Budapest. Hid Közl 88, 79-81 (in Hungarian).

Hugh, R. \& Leifson, E. (1953). The taxonomic significance of fermentative versus oxidative metabolism of carbohydrates by various Gram negative bacteria. J Bacteriol 66, 24-26.

Kimura, M. (1980). A simple method for estimating evolutionary rates of base substitutions through comparative studies of nucleotide sequences. J Mol Evol 16, 111-120.

Kubota, M., Kawahara, K., Sekiya, K., Uchida, T., Hattori, Y., Futamata, H. \& Hiraishi, A. (2005). Nocardioides aromaticivorans sp. nov., a dibenzofuran-degrading bacterium isolated from dioxinpolluted environments. Syst Appl Microbiol 28, 165-174.

Lawson, P. A., Collins, M. D., Schumann, P., Tindall, B. J., Hirsch, P. \& Labrenz, M. (2000). New LL-diaminopimelic acid-containing actinomycetes from hypersaline, heliothermal and meromictic Antarctic Ekho Lake: Nocardioides aquaticus sp. nov. and Friedmanniella [correction of Friedmannielly] lacustris sp. nov. Syst Appl Microbiol 23, 219-229.

Mesbah, M., Premachandran, U. \& Whitman, W. B. (1989). Precise measurement of the $\mathrm{G}+\mathrm{C}$ content of deoxyribonucleic acid by highperformance liquid chromatography. Int J Syst Bacteriol 39, 159-167.

Minnikin, D. E., Collins, M. D. \& Goodfellow, M. (1979). Fatty acid and polar lipid composition in the classification of Cellulomonas, Oerskovia and related taxa. J Appl Bacteriol 47, 87-95.

Murray, R. G. E., Doetsch, R. N. \& Robinov, C. F. (1994). Determinative and cytological light microscopy. In Methods for General and Molecular Bacteriology, pp. 21-41. Edited by P. Gerhardt, R. G. E. Murray, W. A. Wood \& N. R. Krieg. Washington, DC: American Society for Microbiology.

Pearson, W. R. \& Lipman, D. J. (1988). Improved tools for biological sequence comparison. Proc Natl Acad Sci U S A 85, 2444-2448.

Rainey, F. A., Ward-Rainey, N., Kroppenstedt, R. M. \& Stackebrandt, E. (1996). The genus Nocardiopsis represents a phylogenetically coherent taxon and a distinct actinomycete lineage: proposal of Nocardiopsaceae fam. nov. Int J Syst Bacteriol 46, 1088-1092.

Reasoner, D. J. \& Geldreich, E. E. (1985). A new medium for the enumeration and subculture of bacteria from potable water. Appl Environ Microbiol 49, 1-7.

Rzhetsky, A. \& Nei, M. (1992). A simple method for estimating and testing minimum-evolution trees. Mol Biol Evol 9, 945-967.
Saitou, N. \& Nei, M. (1987). The neighbor-joining method: a new method for reconstructing phylogenetic trees. Mol Biol Evol 4, 406425.

Schippers, A., Schumann, P. \& Spröer, C. (2005). Nocardioides oleivorans sp. nov., a novel crude-oil-degrading bacterium. Int J Syst Evol Microbiol 55, 1501-1504.

Smibert, R. M. \& Krieg, N. R. (1994). Phenotypic characterisation. In Methods for General and Molecular Bacteriology, pp. 603-711. Edited by P. Gerhardt, R. G. E. Murray, W. A. Wood \& N. R. Krieg. Washington, DC: American Society for Microbiology.

Stead, D. E., Sellwood, J. E., Wilson, J. \& Viney, I. (1992). Evaluation of a commercial microbial identification system based on fatty acid profiles for rapid, accurate identification of plant pathogenic bacteria. J Appl Bacteriol 72, 315-321.

Tamaoka, J. \& Komagata, K. (1984). Determination of DNA base composition by reversed-phase high-performance liquid chromatography. FEMS Microbiol Lett 25, 125-128.

Tamura, K., Dudley, J., Nei, M. \& Kumar, S. (2007). MEGA4: molecular evolutionary genetics analysis (MEGA) software version 4.0. Mol Biol Evol 24, 1596-1599.

Tarrand, J. J. \& Gröschel, D. H. M. (1982). Rapid, modified oxidase test for oxidase-variable bacterial isolates. J Clin Microbiol 16, 772-774.

Tóth, E. M., Schumann, P., Borsodi, A. K., Kéki, Zs., Kovács, A. L. \& Márialigeti, K. (2008a). Wohlfahrtiimonas chitiniclastica gen. nov., sp. nov., a new gammaproteobacterium isolated from Wohlfahrtia magnifica (Diptera: Sarcophagidae). Int J Syst Evol Microbiol 58, 976-981.

Tóth, E. M., Kéki, Zs., Homonnay, Z. G., Borsodi, A. K., Márialigeti, K. \& Schumann, P. (2008b). Nocardioides daphniae sp. nov., isolated from Daphnia cucullata (Crustacea: Cladocera). Int J Syst Evol Microbiol 58, 78-83.

Yamada, K. \& Komagata, K. (1972). Taxonomic studies on coryneform bacteria. IV. Morphological, cultural, biochemical, and physiological characteristics. J Gen Appl Microbiol 18, 399-416.

Yoon, J.-H., Rhee, S.-K., Lee, J.-S., Park, Y.-H. \& Lee, S. T. (1997). Nocardioides pyridinolyticus sp. nov., a pyridine-degrading bacterium isolated from the oxic zone of an oil shale column. Int J Syst Bacteriol 47, 933-938.

Yoon, J.-H., Cho, Y.-G., Lee, S. T., Suzuki, K., Nakase, T. \& Park, Y.-H. (1999). Nocardioides nitrophenolicus sp. nov., a p-nitrophenoldegrading bacterium. Int J Syst Bacteriol 49, 675-680.

Yoon, J.-H., Kim, I.-G., Kang, K. H., Oh, T.-K. \& Park, Y.-H. (2004). Nocardioides aquiterrae sp. nov., isolated from groundwater in Korea. Int J Syst Evol Microbiol 54, 71-75.

Yoon, J.-H., Kang, S.-J., Lee, M.-H. \& Oh, T.-K. (2008). Nocardioides hankookensis sp. nov., isolated from soil. Int J Syst Evol Microbiol 58, 434-437. 